\title{
Genetic Variability, Heritability and Genetic Advance in Cluster Bean [Cyamopsis tetragonoloba (L.) Taub.] Genotypes
}

\begin{abstract}
Background: Cluster bean commonly known as guar is an important leguminous crop. It is widely exploited as an industrial crop because of its seeds which contain galactomannan rich endosperm. Nutrient rich green pods are used as vegetable for human consumption and plants as fodder for livestock. It is a drought tolerant hardy vegetable, which fixes atmospheric nitrogen. Even though it has great potential as a vegetable and industrial crop, it is not very popular in Kerala. So, there is a need for improvement and development of varieties suitable for climatic condition prevailing in Kerala. Hence, evaluation of germplasm has to be conducted as a preliminary step in-order to study extend of variability available in the germplasm and to identify suitable high yielding genotypes that can be utilized in the crop improvement programme. The present study was conducted to estimate genetic variability, heritability and genetic advance for yield and yield contributing characters among the collected cluster bean genotypes.

Methods: Thirty accessions of cluster bean were evaluated during 2018. The experiment was laid out in randomized block design with two replications. Statistical analysis was employed for estimation of various genetic parameters such as GCV, PCV, heritability and GAM.

Result: The genotypes exhibited wide variability for all the characters studied. High estimates of GCV and PCV were observed for number of branches, number of pod clusters/plant, number of pods/plant, number of pods/cluster, pod weight and pod yield/plant. High heritability coupled with high genetic advance as per cent of mean was observed for plant height, number of branches, number of pod clusters/plant, number of pods/plant, number of pods/cluster, pod weight and pod yield/plant which suggested the presence of addictive gene effects. Hence, pod yield in cluster bean could be improved through direct selection.
\end{abstract}

Key words: Cluster bean, Genetic advance, Genetic variability, Heritability.

\section{INTRODUCTION}

Cluster bean [Cyamopsis tetragonoloba (L) Taub. $2 \mathrm{n}=14$ ] is an important arid legume crop, commonly known as guar. This is a hardy and drought tolerant crop. Extensive tap root system of cluster bean imparts drought tolerance. Due to its drought tolerance it is widely cultivated in arid and semiarid regions. It can also serve as fodder and green manure crop, can enrich the soil by fixing atmospheric Nitrogen (50-60 kg/ha) and add organic matter to soil. It is also widely exploited as an industrial crop because of its seeds which contain galactomannan rich endosperm (Sharma et al., 2014). The guar gum extracted from seeds of cluster bean is found to have application in paper, textile, pharmaceuticals and petroleum industries.

Traditionally the pods are consumed as vegetable. The pods are rich in nutrients like protein, dietary fibre, vitamin A, vitamin C, calcium and iron (Kumar and Singh, 2002). $100 \mathrm{~g}$ of edible pods contain $10.8 \mathrm{~g}$ of carbohydrates, $3.2 \mathrm{~g}$ of protein and $0.4 \mathrm{~g}$ fat. It protects heart from various cardiovascular problems and also works as a good laxative, stimulating bowel movement and improve digestive system.

Even though it has great potential as a vegetable and industrial crop, it is not very popular in Kerala. So, there is a need for improvement and development of varieties suitable for climatic condition prevailing in Kerala. Hence evaluation of germplasm has to be conducted as a preliminary step inorder to study extend of variability available in the germplasm
Department of Vegetable Science, College of Agriculture, Kerala Agricultural University, Thrissur-680 656, Kerala, India.

Corresponding Author: A. Remzeena, Department of Vegetable Science, College of Agriculture, Kerala Agricultural University, Thrissur-680 656, Kerala, India. Email: remzeenaa@gmail.com

How to cite this article: Remzeena, A. and Anitha, P. (2021). Genetic Variability, Heritability and Genetic Advance in Cluster Bean [Cyamopsis tetragonoloba (L.) Taub.] Genotypes. Indian Journal of Agricultural Research. DOI: 10.18805/IJARe.A-5779.

Submitted: 27-03-2021 Accepted: 15-07-2021 Online: 16-09-2021

and to identify suitable high yielding genotypes that can be utilized in the crop improvement programme.

Genetic improvement for quantitative traits depends upon the nature and amount of variability present in the genetic stock and the extent to which the desirable traits are heritable. Knowledge on variability, components of variance such as genotypic coefficient of variation, phenotypic coefficient of variation and heritability help in designing crop improvement program and choice of parental genotypes. The phenotypic expression of plant character is mainly controlled by genetic makeup of the plant, the environment in which it is grown and the interaction between genotype and environment. The observed phenotypic variability have to be divided into different components such 
as genotypic (heritable) and environmental (non-heritable) with suitable parameters such as phenotypic and genotypic coefficient of variation (GCV), heritability in broad sense and genetic advance (GA) based on which selection can be done. Heritability denotes the proportion of phenotype variation contributed by genotype. It indicates only the effectiveness with which selection can be made but do not indicate the genetic progress in a selection cycle. High heritability alone cannot result in efficient selection. Whereas, the estimation of genetic advance help to predict efficiency of selection. Genetic advance denotes the improvement in the mean genotypic values of selected individuals over base population.

\section{MATERIALS AND METHODS}

The present study was conducted in the Department of Vegetable Science, College of Agriculture, Vellanikkara, Kerala Agricultural University, Thrissur during 2018. The experiment was laid out in randomized block design with two replications. Thirty accessions of cluster bean collected from NBPGR, Jodhpur were used in the study. The seeds of each accession were sown at a spacing of $45 \times 45 \mathrm{~cm}$ in plots of $3 \times 2.7 \mathrm{~m}^{2}$. The crop was raised as per the Package of Practices Recommendations Crops, $\mathrm{KAU}(2016)$. In each replication observations were recorded from five plants. Characters such as plant height, number of branches, days to $50 \%$ flowering, days to first fruit set, days to first harvest, number of pod clusters/ plant, number of pods/cluster, number of pods/plant, pod length, pod girth, pod weight, number of seeds/pod, pod yield/plant were recorded.

Statistical analysis was employed for estimation of various genetic parameters. GCV and PCV were estimated by the method suggested by (Burton, 1952), Broad sense Heritability was estimated as the ratio of genotypic variance to phenotypic variance and expressed in percentage
(Falconer, 1981), genetic advance was calculated by using the formula given by (Robinson et al., 1949). Genetic advance as per cent of mean was worked using the method given by (Jhonson et al., 1955).

\section{RESULTS AND DISCUSSION}

Analysis of variance revealed that cluster bean genotypes under study exhibited significant differences for all the characters studied viz., plant height, number of branches, days to $50 \%$ flowering, days to first fruit set, days to first harvest, number of pod clusters/plant, number of pods/ cluster, number of pods/plant, pod length, pod girth, pod weight, number of seeds/pod, pod yield/plant. Results indicated that consider variability exist for all the characters studied and sufficient improvement could be achieved in most of these traits.

Estimate of genotypic and phenotypic variance are of greater use in determining extend of variability present within the breeding material. The estimate of range, mean components of variance, heritability and genetic advance for growth, earliness and yield parameters in cluster bean is given in Table 1. In the present study, high estimates of Phenotypic coefficient of variation (PCV) was recorded for number of branches (40.35), number of pod clusters/plant (26.90), number of pods/plant (36.37), number of pods/ cluster (42.37), pod weight (23.23) and pod yield/plant (28.41) which indicated presence high variability for these traits.

As the estimate of phenotypic variability cannot differentiate between environmental and genetic effects, study of genetic variability is required to partition the real genetic difference from environmental effects. Higher the genotypic coefficient of variation (GCV) more the chances of improvement in that character. In the present study, high estimates of GCV (>20\%) was recorded for number of branches (39.90), number of pod clusters/plant (26.21),

Table 1: Range, mean, GCV, PCV, heritability, genetic advance (GA) and genetic advance as percent mean (GAM) for different characters in cluster bean.

\begin{tabular}{|c|c|c|c|c|c|c|c|}
\hline Characters & Range & Mean & $\begin{array}{c}\text { GCV } \\
(\%)\end{array}$ & $\begin{array}{l}\text { PCV } \\
(\%)\end{array}$ & $\begin{array}{c}\text { Heritability } \\
(\%)\end{array}$ & $\begin{array}{l}\text { GA } \\
(\%)\end{array}$ & $\begin{array}{c}\text { GAM } \\
(\%)\end{array}$ \\
\hline Plant height $(\mathrm{cm})$ & $109.12-200.85$ & 139.04 & 16.74 & 16.94 & 97.59 & 47.36 & 34.06 \\
\hline No. of branches & $0.00-19.20$ & 12.73 & 39.90 & 40.35 & 97.81 & 10.35 & 81.29 \\
\hline Days to $50 \%$ flowering & $22.50-33.00$ & 24.77 & 8.41 & 11.61 & 52.47 & 3.11 & 12.55 \\
\hline Days to first fruit set & $24.50-35.00$ & 25.82 & 3.23 & 9.95 & 10.56 & 0.56 & 2.17 \\
\hline Days to first harvest & $44.50-51.50$ & 47.02 & 2.90 & 4.61 & 39.63 & 1.77 & 3.76 \\
\hline No. of pod clusters/plant & $15.25-62.21$ & 42.48 & 26.21 & 26.90 & 94.90 & 22.34 & 52.59 \\
\hline No. of pods/cluster & $4.50-19.25$ & 8.76 & 41.64 & 42.37 & 96.55 & 7.38 & 84.27 \\
\hline No. of pods/plant & $61.33-383.62$ & 187.06 & 36.17 & 36.37 & 98.91 & 138.61 & 74.10 \\
\hline Pod length (cm) & $5.79-11.80$ & 6.69 & 15.96 & 16.02 & 99.28 & 2.19 & 32.76 \\
\hline Pod girth $(\mathrm{cm})$ & $0.68-1.18$ & 0.82 & 14.04 & 14.97 & 87.92 & 0.22 & 27.12 \\
\hline Pod weight $(\mathrm{g})$ & $1.06-2.46$ & 1.39 & 23.21 & 23.23 & 99.87 & 0.68 & 47.79 \\
\hline No. of seeds/pod & $6.5-9.1$ & 8.07 & 7.76 & 8.72 & 79.29 & 1.15 & 14.24 \\
\hline Pod yield/plant $(\mathrm{g})$ & $148.27-412.83$ & 248.57 & 28.11 & 28.41 & 97.87 & 142.39 & 57.29 \\
\hline
\end{tabular}


number of pods/plant (36.17), number of pods/cluster (41.64), pod weight (23.21) and pod yield/plant (28.11). This indicated the presence of high amount of variability in the genetic stock studied. Hence, selection could be employed for the improvement of these traits. This is in confirmation with the results obtained by Anandhi and Ommen (2007); Vir and Singh (2015); Kumar et al. (2015); Patil et al.(2016); Rishitha et al.(2019); Kgasudi et al.(2019).

Moderate estimate of PCV and GCV (11-20\%) were observed for plant height (16.74), pod length (15.96), pod girth (14.04). This indicated presence of moderate amount of variability. Malaghan et al. (2012) and Girish et al. (2013) also observed moderate GCV for plant height, pod length and girth in cluster bean. Low GCV $(<11 \%)$ were observed for days to $50 \%$ flowering (8.41), days to first fruit set (3.23), days to first harvest (2.90) and number of seeds/pod (7.76). This indicated the narrow genetic base for these traits in the collected accessions and there is limited scope for improvement of these traits through selection. These results are in accordance with Hanchinamani (2004); Girish et al. (2013); Gowd et al. (2019).

Heritability estimates is the percentage of phenotypic variance that is attributed to genetic variance. High heritability of a trait implies that improvement is possible through selection. Whereas, characters with low heritability shows less response to selection. In the present study, very high broad sense heritability (>80\%) was observed for plant height $(97.59 \%)$, number of branches $(97.81 \%)$, number of pod clusters/plant (94.90\%), number of pods/cluster $(96.55 \%)$, number of pods/plant $(98.91 \%)$, pod length $(99.28 \%)$, pod girth $(87.92 \%)$, pod weight $(99.87 \%)$ and pod yield/plant $(97.87 \%)$. Traits like days to $50 \%$ flowering $(52.47 \%)$, day to first harvest $(39.63 \%)$ had moderate heritability whereas, days to first fruit set had very low heritability (10.56\%). Similar results were reported by Anandhi and Ommen (2007); Muthuselvi and Shanthi (2013); Patil et al. (2016); Santhosha et al. (2017); Rishitha et al. (2019). Heritability estimates alone is not enough to provide information about genetic progress that could be made through selection. Hence, heritability estimates along with genetic advance is more useful in predicting the response to selection.

Considering heritability in broad sense along with genetic advance revealed the prevalence of addictive or nonaddictive genetic variance and thus helps in judging the effectiveness of selection more accurately. Genetic advance as percent mean (GAM) for the traits varied from $2.17 \%$ (days to first fruit set) to $84.27 \%$ (number of pods/cluster). In the present study, high heritability coupled with high genetic advance was predicted for plant height, number of branches, number of pod clusters/plant, number of pods/ cluster, number of pods/plant, pod length, pod weight and pod yield/plant. Indicating that these characters may be controlled by addictive gene actions and are likely to respond better to selection. The findings of Muthuselvi and Shanthi (2013); Patil et al. (2016); Kumar et al. (2015); Boghara et al. (2016); Santhosha et al. (2017); Kgasudi et al.(2019) in cluster bean were in same line.

High heritability coupled with moderate to low GAM were observed for number of seeds/pod and days to $50 \%$ flowering. This indicated the prevalence of non-addictive gene actions. Hence, there will be less response to selection. Gowd et al. (2019) also reported similar results for number of seeds/pod in cluster bean. Moderate to low heritability and GAM was observed for days to first fruit set and days to first harvest. These traits also had high PCV compared to GCV. This indicated the influence of environment on these traits and hence, selection would be ineffective. They could be exploited through manifestation of dominance and epistatic components through hybridization followed by selection. These results are in line with the findings of Rai et al. (2012) in cluster bean, Islam et al. (2011) in dolichos bean and Kamaluddin and Ahmed (2011) and Jhanvi et al. (2018) in french bean.

\section{CONCLUSION}

From the present study it can be concluded that traits like plant height, number of branches, number of pod clusters/ plant, number of pods/cluster, number of pods/plant, pod length, pod weight and pod yield/plant have high heritability coupled with high genetic advance as percent of mean (GAM). Hence, these traits could be effectively used in selection indices and also take up for further crop improvement programmes for the development of cluster bean for better yield and yield contributing characters.

\section{REFERENCES}

Anandhi, K. and Ommen, S.K. (2007). Variability heritability of yield and related characters in cluster bean [Cyamopsis tetragonoloba (L) Taub.]. Legume Research. 30(4): 287-289.

Burton, G.W. (1952). Quantitative Inheritance in Grass. Proceedings of $6^{\text {th }}$ International Grassland Congress 1: 277-283

Boghara, M.C., Dhaduk, H.L., Kumar, S. Parekh, M.J., Patel, N.J. and Sharma, R. (2016). Genetic divergence, path analysis and molecular diversity analysis in cluster bean [Cyamopsis tetragonoloba (L.) Taub.]. Industrial Crops and Products 89: 468-477.

Falconer, D.S. (1981). Introduction to Quantitative Genetics. Oliver and Boyd, Edinberg.

Girish, M. H., Gasti, V.D., Shantappa, T., Mastiholi, A.B., Thammaiah, N., Kerutagi, M.G., Mulge, R. (2013). Genetic variability studies in cluster bean [Cyamopsis tetragonoloba $(\mathrm{L})$ Taub.]. Karnataka Journal of Agricultural Science. 26(3): 442-443.

Gowd, Y.M., Reddy, S.S., Priya, T., Kiran, D. and Reddy, R. (2019). Genetic variability studies in cluster bean [Cyamopsis tetragonoloba (L.) Taub]. Plant Archives. 19(2): 3341-3344.

Hanchinamani, N.C. (2004). Studies on genetic variability and genetic divergence in cluster bean [Cyamopsis tetragonoloba (L.) Taub.]. M.Sc. (Hort.) thesis, University of Agricultural Sciences, Dharwad, India, 160p.

Islam, M.S., Rahman, M.M. and Mian, A.K. (2011). Genetic variability, heritability and correlation study in hyacinth bean [Lablab 
purpureus (L. Sweet]. Bangladesh Journal of Agricultural Research. 36(2): 351-354.

Jhanavi, D.R., Patil, H.B., Justin,P., Hadimani, H.P., Mulla, S.W.R., and Sarvamangala, C. (2018). Genetic variability, heritability and genetic advance studies in french bean (Phaseolus vulgaris L.) genotypes. Indian Journal of Agricultural Research. 52 (2): 162-166.

Johnson, H.W. Robinson, H.E. and Comstock, R.E. (1955). Estimate of genetic and environmental variability in soybean. Agronomy Journal. 47: 314-318.

Kgasudi, B.K., Rekha, G.K., Jyothi, K.U. and Sasikala, K. (2019). Variability, heritability and genetic advance for yield and yield attributing characters in cluster bean [Cyamopsis tetragonoloba (L.) Taub.] genotypes. Indian Journal of Agricultural Research. 54. 247-251

KAU (Kerala Agricultural University). (2016). Package of Practices Recommendations: Crops (15 $5^{\text {th }}$ Ed.).Kerala Agricultural University, Thrissur, 392p.

Kumar, D. and Singh, N.B. (2002). Guar in India. Scientific Publishers, Jodhpur. pp. 1-5.

Kumar, V. Ram, R.B., Rajvanshi, S.K. and Dohre, S. (2015). Study on genetic variability, heritability and genetic advance for yield and yield attributing characters in cluster bean [Cyamopsis tetragonoloba (L) Taub.]. International Journal of Agricultural Science and Research. 5(4): 235-246.

Kamaluddin and Ahmed, S. (2011). Variability, correlation and path analysis for seed yield and yield related traits in common beans (Phaseolus vulgaris L.). Indian Journal of Horticulture. 68(1): 56-60.

Malaghan, S.N., Madslageri, M.B., Ganiger, V.M., Bhuvaneshwari, G., Kotikal, Y.H. and Patil, H.B. (2012). Genetic variability and heritability in cluster bean [Cyamopsis tetragonoloba (L) Taub.] for vegetable pod yield and its component character. International Journal of Agricultural Science. 9(2): 765-768.
Muthuselvi, R. and Shanthi, A. (2013). Variability, heritability and genetic advance in cluster bean [Cyamopsis tetragonoloba (L). Taub.]. Advance Research Journal of Crop Improvement. 4(2): 106-109.

Patil, B.T., Bhalekar, M.N., Musmade, A.M., Shinde, K.G. and Magar, V.G. (2016). Genetic variability and heritability studies in cluster bean [Cyamopsis tetragonoloba (L) Taub.]. Bioinfolet. 13(2A): 247-250.

Rai, S.P., Dharmatti, P.R., Shashidhar, T.R., Patil, R.V. and Patil, B.R. (2012). Genetic variability studies in clusterbean [Cyamopsis tetragonoloba (L). Taub]. Karnataka Journal of Agricultural Science. 25(1): 108-111.

Rishitha, G., Lakshmi, R.R., Jyothi, K.U. and Krishna, K.U. (2019). Studies on Genetic variability, heritability and genetic advance for yield and yield attributing characters in cluster bean [Cyamopsis tetragonoloba (L). Taub.]. International Journal of Current Microbiology and Applied Sciences. 8(8): 1307-1312.

Robinson, H.F., Comstock, R.E. and Harvey, P.M. (1949). Estimates of heritability and degree of dominance in corn. Agronomy Journal. 41: 353-359.

Santhosha, G.R., Shashikanth, E., Gasti, V.D., Prabhuling, G., Rathod, V.D. and Mulge, R. (2017). Genetic variability studies in cluster bean [Cyamopsis tetragonoloba (L.) Taub.] for growth, yield and quality parameters. Legume Research. 40((2): 232-236.

Sharma, P., Sharma, V. and Kumar, V. (2014). Genetic diversity analysis of cluster bean [Cyamopsis tetragonoloba (L.) Taub.] genotypes using RAPD and ISSR Markers. Journal of Agricultural Science and Technology. 16: 433-443.

Vir,O. and Singh, A.K. (2015). Variability and correlation analysis in the germplasm of cluster bean [Cyamopsis tetragonoloba (L) Taub.] in hyper hot arid climate of western Indian. Legume Research. 38(1): 37-42. 